\title{
IN VITRO ANTI-DIABETIC ACTIVITY OF MICROENCAPSULATED AND NON-ENCAPSULATED ASTAXANTHIN
}

\author{
V. SUGANYA, V. ANURADHA*, M. SYED ALI, P. SANGEETHA, P. BHUVANA \\ Department of Biochemistry, Mohamed Sathak College of arts and Science, Sholinganallur, Chennai, Tamil Nadu, India \\ Email: srisugan20@gmail.com
}

Received: 24 May 2017, Revised and Accepted: 22 Jul 2017

\begin{abstract}
Objective: Diabetes is a long term condition which indicates the high blood pressure. The symptoms indicates, polyuria (frequent urination), they will become increasingly thirsty (polydipsia) and hungry (polyphagia). Many drugs has been discovered for curing diabetes. Recent studies reported that the administration of astaxanthin reduces the blood pressure in the diabetic patient. Astaxanthin is a powerful antioxidant found in wide variety of aquatic living organism which has wide applications in pharmacological studies.
\end{abstract}

Methods: In vitro antidiabetic study of both encapsulated and non-encapsulated astaxanthin such as DNSA method, starch-iodine color assay method and $\alpha$ glycosidase enzymes assay was carried out.

Results: The results of the present study indicated that both encapsulated and non-encapsulated astaxanthin shows higher antidiabetic activity in all the method. Each test samples possess the best activity when compared to standard drug acarbose.

Conclusion: The present study, it is concluded that both non-encapsulated and encapsulated astaxanthin exhibit good antidiabetic activity.

Keywords: Astaxanthin, Anti-diabetic, DNSA, Starch-iodine, Acarbose, $\alpha$ glycosidase

(C) 2017 The Authors. Published by Innovare Academic Sciences Pvt Ltd. This is an open access article under the CC BY license (http://creativecommons.org/licenses/by/4.0/)

DOI: http://dx.doi.org/10.22159/ijcpr.2017v9i5.22147

\section{INTRODUCTION}

Diabetes is one of the major causes of premature death worldwide. Every ten second a person dies from diabetes related causes mainly from cardiovascular complications. Metabolic disease, including dyslipidemia and diabetes, constitutes a major emerging health crisis in the world. The WHO, in the 2009 report, states that high blood plasma ranked first in the list of leading global risks for mortality and accounted for 7.5 million deaths in the world in 2004 [1]. According to reports, 415 million people worldwide were diabetic in 2015, most of them suffering from Type II diabetes [2].

Diabetes, which is diagnosed based on blood plasma hyperglycemia, has been linked to lipid overload and abdominal obesity and may synergize with these conditions to promote negative clinical outcomes $[3,4]$. Although the symptoms and clinical pathology and physiology of these conditions are well understood, the question of pharmacologic treatment of dyslipidemia and diabetes remains unresolved well. The marine world, due to its phenomenal biodiversity, is a rich natural resource of many biologically active compounds such as polyunsaturated fatty acids (PUFAs), sterols, proteins, polysaccharides, antioxidants and pigments. People worldwide know that marine foods participate in human health promotion. A diet rich in marine products is considered to result in a lower incidence of diabetes, cancer and obesity. To date, many of reports have also showed that bioactive compounds from marine organisms, including Fucoxanthin, Astaxanthin, Marine Collagen Peptides, Dieckol and Krill Oil, exert a positive influence on metabolic dysfunction (diabetes and obesity) [1].

Astaxanthin, a red-orange carotenoid pigment, is a biological antioxidant that naturally found in a wide variety of aquatic living organisms, such as shrimp, crab, and salmon [5]. The green micro algae Haematococcus pluvialis and the red yeast Phaffi a rhodozyma are common sources of natural astaxanthin [5]. Astaxanthin has shown various pharmacological activities, including antiinflammatory [6, 7] and antidiabetic activities [8], as well as antioxidative effects [9-12]. Diabetes mellitus is strongly associated with oxidative stress, which can be a consequence of increased free radical production, reduced antioxidant defences or both [13].
Oxidative stress induced by hyperglycemia possibly causes the dysfunction of pancreatic b-cells and various forms of tissue damage in patients with diabetes mellitus. It was found that astaxanthin could diminish the oxidative stress caused by hyperglycemia in the pancreatic $\beta$ cells, significantly improve glucose tolerance, increase serum insulin levels, and decrease blood glucose levels, indicating that astaxanthin might exert beneficial effects on pancreatic b-cell function and could protect pancreatic b-cells against glucose toxicity by preventing the progressive destruction of these cells [8]. The main objective of the present study is to investigate the antidiabetic activity for both encapsulated and non-encapsulated astaxanthin.

\section{MATERIALS AND METHODS}

\section{Microencapsulation of astaxanthin using different agents}

Astaxanthin purchased from Rudra Bio ventures Pvt Ltd, Bangalore was encapsulated using four different agents by ionotropic gelation method. In the first method, microencapsulated astaxanthin was prepared by using sodium alginate and calcium chloride [14, 15, 40]. In the second method, microencapsulated astaxanthin was prepared using sodium alginate and chitosan [16]. In the third method, chitosan-Tripolyphosphate was used to produce microencapsulated astaxanthin $[17,18]$. In the fourth method, liposome encapsulated astaxanthin was carried out by the method [19]. These test samples (Both encapsulated and non-encapsulated astaxanthin) were used to study the antidiabetic activity using four different methods.

\section{In vitro anti-diabetic activity}

\section{$\alpha$ amylase enzyme assay (DNSA method)}

Starch solution $(0.1 \% \mathrm{w} / \mathrm{v})$ was prepared by stirring $0.1 \mathrm{~g}$ of starch in $100 \mathrm{ml}$ of $16 \mathrm{mmol}$ of sodium acetate buffer. The enzyme solution was prepared by mixing $27.5 \mathrm{mg}$ of alpha-amylase in $100 \mathrm{ml}$ of distilled water. The colorimetric reagent was prepared by mixing the sodium potassium tartrate solution and 3, 5 Di-nitro salicylic acid solution at $96 \mathrm{mmol}$ concentration $[20,21]$. The control tube contains an only reagent and the test sample in the range of 100$500 \mu \mathrm{g} / \mathrm{ml}$ was prepared. From this, $500 \mu \mathrm{l}$ of sample was mixed with $500 \mu \mathrm{l}$ of starch solution and $500 \mu \mathrm{l}$ of alpha-amylase solution 
which is incubated at $37^{\circ} \mathrm{C}$ for $10 \mathrm{~min}$. The reaction was stopped by the addition of $1 \mathrm{ml}$ of 3, 5 Di-nitro salicylic acids and incubated in boiling water bath for $5 \mathrm{~min}$, cooled at room temperature. The reaction mixture was then diluted by adding $10 \mathrm{ml}$ of distilled water. The absorbance was measured at $540 \mathrm{~nm}[22,23,24]$. Control was tested by replacing test sample with DMSO. The similar procedure were also followed for the standard drug Acarbose. The percentage of inhibition was calculated using the formula:

$\%$ inhibition $=[($ O.D. of control-O.D. of test sample $) / O . D$. of control $]$ $\times 100$

\section{$\alpha$ amylase enzyme assay (Starch-Iodine color assay method)}

Screening of test samples for $\alpha$-amylase inhibitors was carried out according to $[25,26]$ with slight modification based on the starchiodine test. Test samples of varied concentrations in $500 \mu \mathrm{L}$ were added to $500 \mu \mathrm{L}$ of $0.02 \mathrm{M}$ sodium phosphate buffer (pH6.9 containing $6 \mathrm{mmol}$ sodium chloride) containing 0.04 units of the $\alpha$ amylase solution and were incubated at $37^{\circ} \mathrm{C}$ for $10 \mathrm{~min}$.

Then $500 \mu \mathrm{L}$ soluble starch $(1 \%, \mathrm{w} / \mathrm{v})$ was added to each reaction well and incubated at $37^{\circ} \mathrm{C}$ for $15 \mathrm{~min} .1 \mathrm{M} \mathrm{HCl}(20 \mu \mathrm{L})$ was added to stop the enzymatic reaction, followed by the addition of $100 \mu \mathrm{L}$ of iodine reagent ( $5 \mathrm{mmol} \mathrm{I} 2$ and $5 \mathrm{mmol} \mathrm{KI}$ ). The color change was noted and the absorbance was read at $620 \mathrm{~nm}$ on a microplate reader. The control reaction representing 100\% enzyme activity were taken. Inhibition of enzyme activity was calculated as:

$\%$ inhibition $=[($ O.D. of control-O.D. of test sample $) /$ O.D. of control $]$ $\times 100$

\section{$\alpha$ glucosidase enzyme assay}

The inhibitory activity of $\alpha$-glucosidase enzyme was determined by $1 \mathrm{ml}$ solution of starch substrate $(2 \% \mathrm{w} / \mathrm{v}$ maltose or sucrose) with $0.2 \mathrm{M}$ Tris buffer $\mathrm{pH} 8.0$ and $1 \mathrm{ml}$ of test samples in the range of $100-500 \mu \mathrm{g} / \mathrm{ml}$ were incubated separately for $5 \mathrm{~min}$ at $37^{\circ} \mathrm{C}$. The reaction was initiated by adding $1 \mathrm{ml}$ of alpha-glucosidase enzyme $(1 \mathrm{U} / \mathrm{ml})$ to it followed by incubation for $40 \mathrm{~min}$ at $35^{\circ} \mathrm{C}$. Then the reaction was terminated by the addition of $2 \mathrm{ml}$ of $6 \mathrm{~N} \mathrm{HCl}$. Then the intensity of the color was measured at $540 \mathrm{~nm}[27,20,24]$. A control experiment was done by replacing the test sample with DMSO and also for a standard drug Acarbose [28, 29, 30]. Percentage of inhibition was calculated by the formula:

$\%$ inhibition $=[($ O.D. of control-O.D. of test sample $) /$ O.D. of control $]$ $\times 100$

$\alpha$ glucosidase enzyme assay (alternate method)

The $\alpha$-glucosidase inhibitory activity was determined according to a modified procedure $[31,32]$. Briefly, $50 \mu \mathrm{l}$ of $0.1 \mathrm{M}$ potassium phosphate buffer ( $\mathrm{pH6} .9$ ) was pre-incubated with $50 \mu \mathrm{l}$ of reduce dglutathione (1 mgml-1), $20 \mu \mathrm{l}$ a-glucosidase (1Uml-1 in $0.1 \mathrm{M}$ phosphate buffer, $\mathrm{pH} 6.9$ and $20 \mu \mathrm{l}$ of test samples at $37^{\circ} \mathrm{C}$ for $10 \mathrm{~min}$. After the incubation, $20 \mu \mathrm{l}$ pNPG was added and the mixture was further incubated at $37^{\circ} \mathrm{C}$ for $30 \mathrm{~min}$. The reaction was terminated by adding $1 \mathrm{ml}$ of 0.1 Msodiumcarbonate. The absorbance of the samples and control were taken at $405 \mathrm{~nm}$ against a blank devoid of pNPG and sample. The control reaction (with 100\% enzyme activity) contained buffer or DMSO instead of the irrespective samples while acarbose was used as a positive control. The inhibitory activity was calculated by using the following Equation:

$\%$ inhibition $=[($ O.D. of control-O.D. of test sample $) /$ O.D. of control $]$ $\times 100$

\section{Statistical analysis}

The statistical analyses for all the experiments were done using Excel 2013 through the statistical formula. Experimental data were expressed as mean \pm SD and IC 50 values were calculated. The experiment was performed in triplicates for all the test samples.

\section{RESULTS}

\section{In vitro anti-diabetic activity}

\section{In vitro Alpha-amylase inhibitory activity (DNSA method).}

In the present study, astaxanthin was encapsulated using four different methods were investigated for their potential to inhibit $\alpha$ amylase activity and $\alpha$-glucosidase activity. Five different concentrations viz., 250,500, 750, 1000 and $1250 \mu \mathrm{g} / \mathrm{ml}$ of test samples were separately tested for the inhibition of $\alpha$-amylase activity and $\alpha$-glucosidase activity along with standard acarbose.

Table 1: In vitro Alpha-amylase inhibitory activity (DNSA method) of standard drug acarbose

\begin{tabular}{lll}
\hline Content & Concentration $(\boldsymbol{\mu g} / \mathbf{m l})$ & mean \pm SD percentage \\
\hline Blank & - & 0.00 \\
S1 & 250 & $32.3 \pm 0.100$ \\
S2 & 500 & $51.1 \pm 0.058$ \\
S3 & 750 & $66.2 \pm 0.053$ \\
S4 & 1000 & $82.9 \pm 0.100$ \\
S5 & 1250 & $99.2 \pm 0.058$ \\
\hline
\end{tabular}

Table 2: In vitro Alpha-amylase inhibitory activity (DNSA method) percentage for different concentration of test samples

\begin{tabular}{|c|c|c|c|c|c|}
\hline $\begin{array}{l}\text { Concentration } \\
(\mu \mathrm{g} / \mathrm{ml})\end{array}$ & $\begin{array}{l}\text { Non-encapsulated astaxanthin } \\
\text { mean } \pm S D \text { percentage }\end{array}$ & $\begin{array}{l}\text { ME } 1 \text { mean } \pm S D \\
\text { percentage }\end{array}$ & $\begin{array}{l}\text { ME } 2 \text { mean } \pm S D \\
\text { percentage }\end{array}$ & $\begin{array}{l}\text { ME } 3 \text { mean } \pm S D \\
\text { percentage }\end{array}$ & $\begin{array}{l}\text { ME } 4 \text { mean } \pm S D \\
\text { percentage }\end{array}$ \\
\hline 250 & $19.53 \pm 0.115$ & $19.37 \pm 0.100$ & $19.79 \pm 0.058$ & $19.95 \pm 0.058$ & $20.32 \pm 0.100$ \\
\hline 500 & $35.04 \pm 0.100$ & $34.83 \pm 0.153$ & $35.30 \pm 0.058$ & $35.57 \pm 0.058$ & $36.04 \pm 0.115$ \\
\hline 750 & $56.46 \pm 0.058$ & $56.31 \pm 0.058$ & $56.83 \pm 0.100$ & $57.10 \pm 0.115$ & $57.57 \pm 0.115$ \\
\hline 1000 & $73.77 \pm 0.100$ & $73.56 \pm 0.058$ & $74.35 \pm 0.153$ & $74.62 \pm 0.058$ & $75.04 \pm 0.100$ \\
\hline 1250 & $87.97 \pm 0.100$ & $87.81 \pm 0.153$ & $88.92 \pm 0.058$ & $89.08 \pm 0.058$ & $98.82 \pm 0.115$ \\
\hline IC 50 Values & 685.169 & 687.703 & 679.168 & 675.780 & 669.129 \\
\hline
\end{tabular}

Among all the test samples (both encapsulated and nonencapsulated astaxanthin) the ME 4 at $1250 \mu \mathrm{g} / \mathrm{ml}$ concentration, had the highest amylase inhibition of $89.82 \%$ followed by ME 2 and ME 3 with inhibition of $88.92 \%$ and $89.08 \%$ respectively. ME 1 and non-encapsulated astaxanthin showed the inhibition of $87.81 \%$ and $87.97 \%$ at concentration $1250 \mu \mathrm{g} / \mathrm{ml}$. The standard drug acarbose showed the percentage of inhibition $87.55 \%$ at concentration 1250 $\mu \mathrm{g} / \mathrm{ml}$ when compared with the test samples. The graph was represented in Graph 1 and Graph 2.
The IC 50 values were also calculated from the percentage of inhibition by each samples. The IC 50 values of standard drug acarbose was $690.830 \mu \mathrm{g} / \mathrm{ml}$ which is compared with test samples such as non-encapsulated astaxanthin, ME 1, ME 2, ME 3 and ME 4 that possessed $685.169 \mu \mathrm{g} / \mathrm{ml}, 687.703 \mu \mathrm{g} / \mathrm{ml}, 679.168 \mu \mathrm{g} / \mathrm{ml}$, $675.168 \mu \mathrm{g} / \mathrm{ml}$ and $669.129 \mu \mathrm{g} / \mathrm{ml}$ respectively (table 1 and table 2). Thus, all the test samples showed highest $\alpha$-amylase inhibition at different concentration $(250 \mu \mathrm{g} / \mathrm{ml}$ to $1250 \mu \mathrm{g} / \mathrm{ml})$ than standard drug acarbose. 


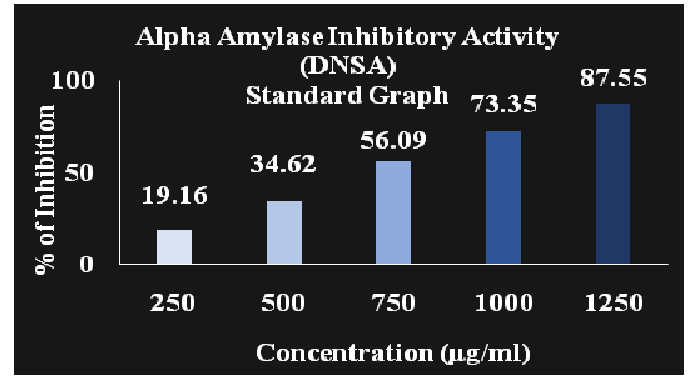

Graph 1: In vitro Alpha-amylase inhibitory activity (DNSA method) standard drug acarbose

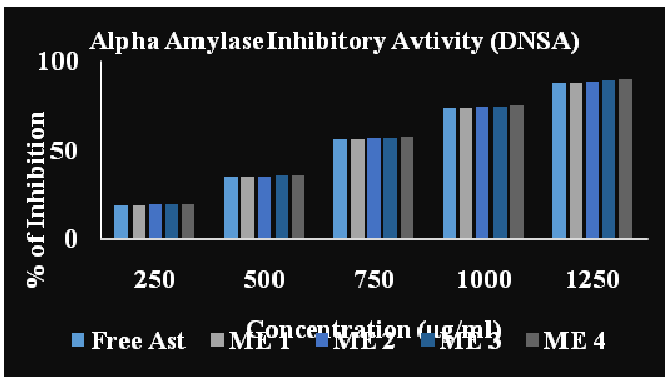

Graph 2: In vitro Alpha-amylase inhibitory activity (DNSA method) for different concentration of test samples

Table 3: In vitro Alpha-amylase inhibitory activity (Starch-Iodine color assay method) of standard drug acarbose

\begin{tabular}{lll}
\hline Content & Concentration $(\boldsymbol{\mu g} / \mathbf{m l})$ & mean \pm SD percentage \\
\hline Blank & - & 0.00 \\
S1 & 250 & $19.84 \pm 0.211$ \\
S2 & 500 & $35.01 \pm 0.037$ \\
S3 & 750 & $60.07 \pm 0.091$ \\
S4 & 1000 & $75.28 \pm 0.042$ \\
S5 & 1250 & $94.34 \pm 0.103$ \\
\hline
\end{tabular}

Table 4: In vitro Alpha-amylase inhibitory activity (Starch-Iodine color assay method) percentage for different concentration of test samples

\begin{tabular}{|c|c|c|c|c|c|}
\hline $\begin{array}{l}\text { Concentration } \\
(\mu \mathrm{g} / \mathrm{ml})\end{array}$ & $\begin{array}{l}\text { Non-encapsulated astaxanthin } \\
\text { mean } \pm \text { SD percentage }\end{array}$ & $\begin{array}{l}\text { ME } 1 \text { mean } \pm \text { SD } \\
\text { percentage }\end{array}$ & $\begin{array}{l}\text { ME } 2 \text { mean } \pm S D \\
\text { percentage }\end{array}$ & $\begin{array}{l}\text { ME } 3 \text { mean } \pm \text { SD } \\
\text { percentage }\end{array}$ & $\begin{array}{l}\text { ME } 4 \text { mean } \pm S D \\
\text { percentage }\end{array}$ \\
\hline 250 & $18.37 \pm 0.115$ & $19.20 \pm 0.093$ & $20.53 \pm 0.113$ & $19.84 \pm 0.141$ & $21.17 \pm 0.191$ \\
\hline 500 & $32.55 \pm 0.132$ & $36.93 \pm 0.051$ & $34.12 \pm 0.121$ & $33.23 \pm 0.072$ & $35.40 \pm 0.116$ \\
\hline 750 & $55.10 \pm 0.051$ & $55.64 \pm 0.003$ & $57.61 \pm 0.213$ & $56.23 \pm 0.063$ & $57.56 \pm 0.053$ \\
\hline 1000 & $71.54 \pm 0.033$ & $72.82 \pm 0.001$ & $72.43 \pm 0.115$ & $71.54 \pm 0.041$ & $73.36 \pm 0.051$ \\
\hline 1250 & $84.64 \pm 0.001$ & $85.57 \pm 0.012$ & $85.92 \pm 0.043$ & $86.66 \pm 0.004$ & $88.08 \pm 0.158$ \\
\hline IC 50 Values & 714.438 & 690.224 & 689.056 & 699.113 & 675.573 \\
\hline
\end{tabular}

In vitro Alpha-amylase inhibitory activity (Starch-Iodine color assay method)

We investigated the encapsulated and non-encapsulated astaxanthin as well as standard drug acarbose for their $\alpha$-amylase inhibitory activities using starch iodine color assay. The OD values were noted in table 3 and table 4.

When we compared the nonencapsulated and encapsulated astaxanthin, the maximum activity at $1250 \mu \mathrm{g} / \mathrm{ml}$ was exhibited by ME 4 (88.08\%) followed by ME 3 (86.66\%) and ME 2 (85.92\%). Non-encapsulated astaxanthin and ME 1 test sample exhibit $84.64 \%$ and $85.57 \%$ which is similar to other test samples. Standard drug acarbose possessed very high inhibition of above $94.34 \%$ at concentration $1250 \mu \mathrm{g} / \mathrm{ml}$ which is greater than that of the test samples. At concentration $250 \mu \mathrm{g} / \mathrm{ml}$ the test samples such as nonencapsulated astaxanthin, ME 1 , ME 2, ME 3 and ME 4 possessed $18.37 \%, 19.20 \%, 20.53 \%, 19.84 \%$ and $21.17 \%$ respectively. The standard exhibit maximum of $19.84 \%$ when compared with all other test samples (Graph 3 and Graph 4). The IC 50 values of standard drug, non-encapsulated astaxanthin and encapsulated astaxanthin was $658.755 \mu \mathrm{g} / \mathrm{ml}, 714.438 \mu \mathrm{g} / \mathrm{ml}, 690.224 \mu \mathrm{g} / \mathrm{ml}, 689.056 \mu \mathrm{g} / \mathrm{ml}$, $699.113 \mu \mathrm{g} / \mathrm{ml}$ and $675.573 \mu \mathrm{g} / \mathrm{ml}$ respectively.

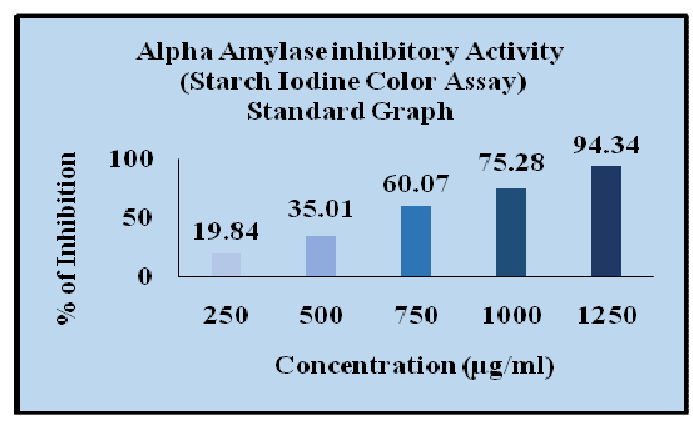

Graph 3: In vitro Alpha-amylase inhibitory activity (StarchIodine color assay method) of standard drug acarbose.

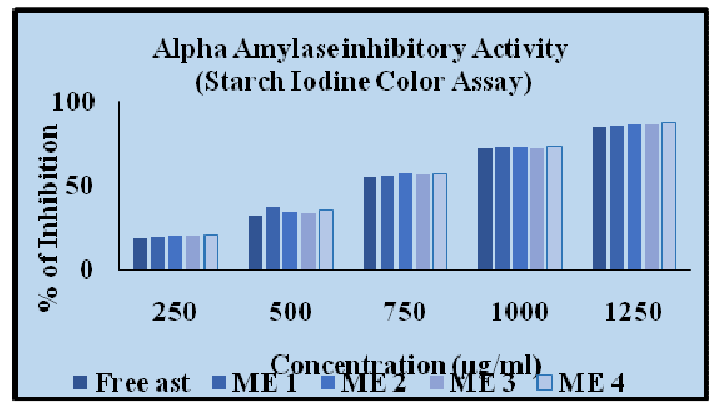

Graph 4: In vitro Alpha-amylase inhibitory activity (Starch-Iodine color assay method) for different concentration of test samples 
In vitro Alpha-glucosidase inhibitory activity

Table 5: In vitro Alpha-glucosidase inhibitory activity of standard drug ascorbose

\begin{tabular}{|c|c|c|c|}
\hline Content & Concentration $(\mu \mathrm{g} / \mathrm{ml})$ & mean \pm SD percentage & IC 50 values \\
\hline Blank & - & 0.00 & 674.687 \\
\hline S1 & 250 & $16.67 \pm 0.158$ & \\
\hline S2 & 500 & $38.02 \pm 0.058$ & \\
\hline S3 & 750 & $61.98 \pm 0.208$ & \\
\hline S4 & 1000 & $71.30 \pm 0.238$ & \\
\hline S5 & 1250 & $88.76 \pm 0.118$ & \\
\hline
\end{tabular}

The results of the $\alpha$-glucosidase are summarized in table 5 and table 6 . All the test samples showed the varying effect on $\alpha$-glucosidase activity. The standard drug showed maximum inhibition with the highest value of $88.76 \%$ seen at $1250 \mu \mathrm{g} / \mathrm{ml}$ concentration. Among the test sample, the highest value was obtained by ME $474.30 \%$ and ME $370.83 \%$ at concentration $1250 \mu \mathrm{g} / \mathrm{ml}$. Compared to these test samples non-encapsulated astaxanthin, ME 1 and ME 2 possessed $68.96 \%, 64.93 \%$ and $67.46 \%$ (Graph 5 and Graph 6) respectively.

Table 6: In vitro Alpha-glucosidase inhibitory activity percentage for different concentration of test samples

\begin{tabular}{|c|c|c|c|c|c|}
\hline $\begin{array}{l}\text { Concentration } \\
(\mu \mathrm{g} / \mathrm{ml})\end{array}$ & $\begin{array}{l}\text { Non-encapsulated astaxanthin } \\
\text { mean } \pm \text { SD percentage }\end{array}$ & $\begin{array}{l}\text { ME } 1 \text { mean } \pm \text { SD } \\
\text { percentage }\end{array}$ & $\begin{array}{l}\text { ME } 2 \text { mean } \pm S D \\
\text { percentage }\end{array}$ & $\begin{array}{l}\text { ME } 3 \text { mean } \pm \text { SD } \\
\text { percentage }\end{array}$ & $\begin{array}{l}\text { ME } 4 \text { mean } \pm S D \\
\text { percentage }\end{array}$ \\
\hline 250 & $14.79 \pm 0.178$ & $13.44 \pm 0.113$ & $14.37 \pm 0.167$ & $14.79 \pm 0.153$ & $15.22 \pm 0.123$ \\
\hline 500 & $25.61 \pm 0.143$ & $24.58 \pm 0.134$ & $25.28 \pm 0.153$ & $26.45 \pm 0.124$ & $28.89 \pm 0.146$ \\
\hline 750 & $46.54 \pm 0.243$ & $43.73 \pm 0.234$ & $45.60 \pm 0.145$ & $49.20 \pm 0.153$ & $50.23 \pm 0.126$ \\
\hline 1000 & $59.93 \pm 0.232$ & $56.55 \pm 0.156$ & $58.38 \pm 0.178$ & $62.41 \pm 0.156$ & $65.26 \pm 0.174$ \\
\hline 1250 & $68.96 \pm 0.134$ & $64.93 \pm 0.145$ & $67.46 \pm 0.103$ & $70.83 \pm 0.183$ & $74.30 \pm 0.126$ \\
\hline IC 50 Values & 869.760 & 923.286 & 889.683 & 838.895 & 802.093 \\
\hline
\end{tabular}

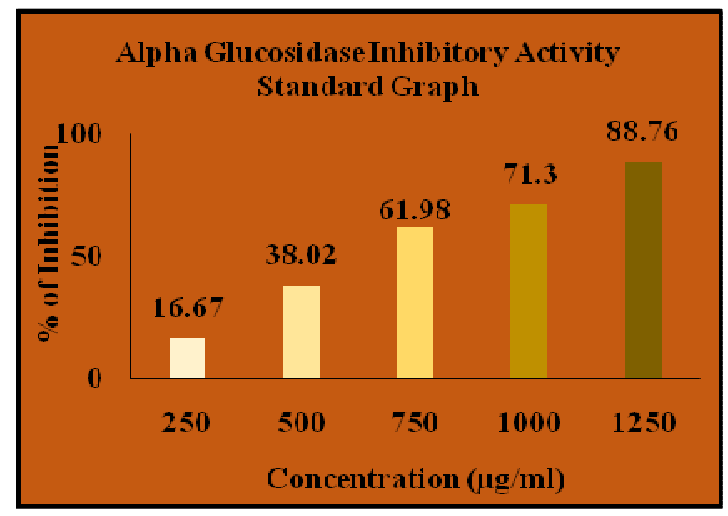

Graph 5: In vitro Alpha-glucosidase inhibitory activity of standard drug acarbose

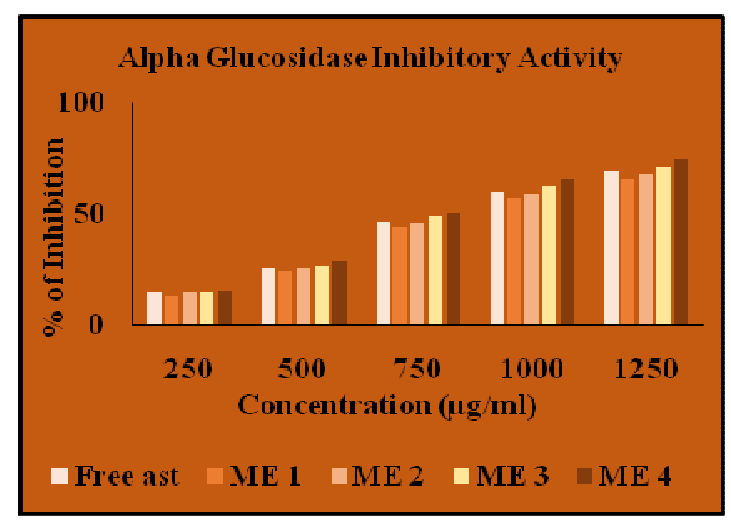

Graph 6: In vitro Alpha-glucosidase inhibitory activity for different concentration of test samples
The IC 50 values were also evaluated from the percentage of inhibition by each test samples. Test samples such as nonencapsulated astaxanthin, ME 1, ME 2, ME 3 and ME 4 showed IC 50 values of $869.760,923.286,889.683,838.895$ and $802.093 \mu \mathrm{g} / \mathrm{ml}$ along with standard drug acarbose that possessed $674.687 \mu \mathrm{g} / \mathrm{ml}$.

In vitro Alpha-glucosidase inhibitory activity (Alternative method)

The result of In vitro Alpha-glucosidase inhibitory activity (Alternative method) was given in table 7 to table 8 . All samples showed maximum inhibition at $1250 \mu \mathrm{g} / \mathrm{ml}$ and least inhibition at $250 \mu \mathrm{g} / \mathrm{ml}$. At concentration $1250 \mu \mathrm{g} / \mathrm{ml}$ the test samples such as non-encapsulated astaxanthin, ME 1, ME 2, ME 3 and ME 4 produced $88.68 \%, 83.11 \%, 85.53 \%, 84.37 \%$ and $89.94 \%$ along with standard i.e. $90.21 \%$. The least inhibition at $250 \mu \mathrm{g} / \mathrm{ml}$ of concentration were recorded by test samples i.e. $18.96 \%, 17.61 \%, 16.98 \%, 18.15 \%$ and $19.95 \%$. The standard drug also exhibits similar percentage of inhibition $19.32 \%$. The graph was plotted against the percentage of inhibition and concentration for both standard and test samples indicated in Graph 7 and Graph 8.

Table 7: In vitro Alpha-glucosidase inhibitory activity (Alternative method) of standard drug acarbose

\begin{tabular}{lll}
\hline Content & Concentration $(\boldsymbol{\mu g} / \mathbf{m l})$ & mean \pm SD percentage \\
\hline BLANK & - & 0.00 \\
S1 & 250 & $19.32 \pm 0.141$ \\
S2 & 500 & $39.71 \pm 0.017$ \\
S3 & 750 & $58.22 \pm 0.043$ \\
S4 & 1000 & $75.83 \pm 0.221$ \\
S5 & 1250 & $90.21 \pm 0.107$ \\
\hline
\end{tabular}


Table 8: In vitro Alpha-glucosidase inhibitory activity (Alternative method) percentage for different concentration of test samples

\begin{tabular}{|c|c|c|c|c|c|}
\hline $\begin{array}{l}\text { Concentration } \\
(\mu \mathrm{g} / \mathrm{ml})\end{array}$ & $\begin{array}{l}\text { Non-encapsulated astaxanthin } \\
\text { mean } \pm \text { SD percentage }\end{array}$ & $\begin{array}{l}\text { ME } 1 \text { mean } \pm S D \\
\text { percentage }\end{array}$ & $\begin{array}{l}\text { ME } 2 \text { mean } \pm S D \\
\text { percentage }\end{array}$ & $\begin{array}{l}\text { ME } 3 \text { mean } \pm \text { SD } \\
\text { percentage }\end{array}$ & $\begin{array}{l}\text { ME } 4 \text { mean } \pm S D \\
\text { percentage }\end{array}$ \\
\hline 250 & $18.96 \pm 0.189$ & $17.61 \pm 0.043$ & $16.98 \pm 0.191$ & $18.15 \pm 0.231$ & $19.95 \pm 0.097$ \\
\hline 500 & $37.35 \pm 0.119$ & $35.22 \pm 0.057$ & $36.12 \pm 0.117$ & $36.66 \pm 0.145$ & $38.27 \pm 0.063$ \\
\hline 750 & $55.71 \pm 0.113$ & $53.46 \pm 0.061$ & $53.37 \pm 0.102$ & $54.27 \pm 0.173$ & $56.33 \pm 0.037$ \\
\hline 1000 & $71.97 \pm 0.210$ & $68.55 \pm 0.113$ & $68.46 \pm 0.134$ & $69.72 \pm 0.029$ & $72.60 \pm 0.183$ \\
\hline 1250 & $88.68 \pm 0.173$ & $83.11 \pm 0.182$ & $85.53 \pm 0.165$ & $84.37 \pm 0.075$ & $89.94 \pm 0.197$ \\
\hline IC 50 Values & 684.879 & 725.811 & 719.134 & 710.211 & 672.294 \\
\hline
\end{tabular}

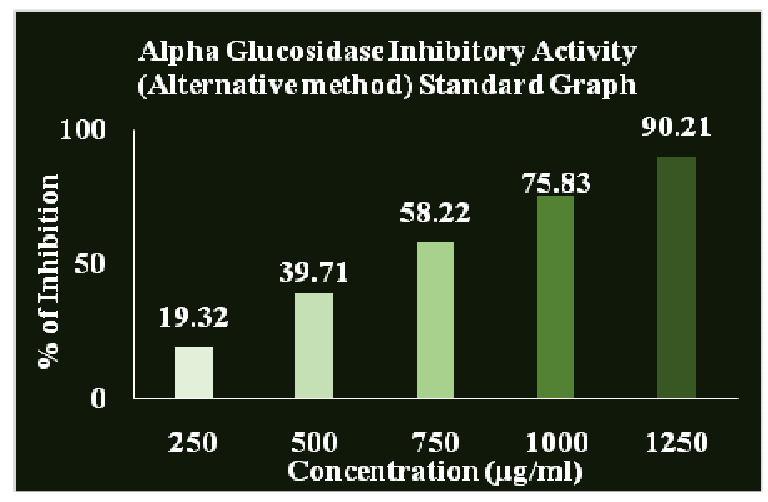

Graph 7: In vitro Alpha-glucosidase inhibitory activity (Alternative method) of standard drug acarbose

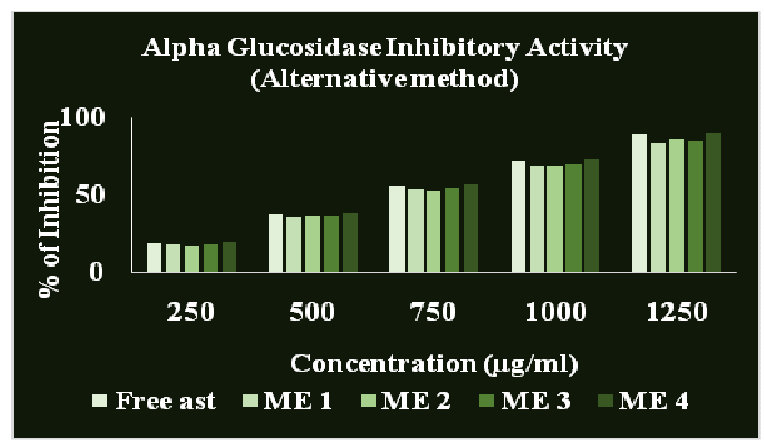

Graph 8: In vitro Alpha-glucosidase inhibitory activity (Alternative method) for different concentration of test samples

\section{DISCUSSION}

Lack of insulin affects the metabolism of carbohydrates, proteins, fat and causes significance disturbance of water and electrolyte homeostasis [33]. Recent advances in understanding the activity of intestinal enzymes ( $\alpha$-amylase and $\alpha$-glucosidase both are important in carbohydrate digestion and glucose absorption) have leads to the development of newer pharmacological agents. A high postprandial blood glucose response is associated with micro-and macro-vascular complications in diabetes and is more strongly associated with the risk for cardiovascular diseases than are fasting blood glucose. $\alpha$ Glucosidase enzymes in the intestinal lumen and in the brush border membrane play main roles in carbohydrate digestion to degrade starch and oligosaccharides to monosaccharides before they can be absorbed. It was proposed that suppression of the activity of such digestive enzymes would delay the degradation of starch and oligosaccharides, which would, in turn, cause a decrease in the absorption of glucose and consequently the reduction of postprandial blood glucose level elevation [34].

Alpha-glucosidase inhibitor retards the digestion of carbohydrates and slows down the absorption. Acarbose and miglitol are a competitive inhibitor of $\alpha$-glucosidases and reduces absorption of starch and disaccharides [35]. Hence one of the therapeutic approaches for reducing postprandial (PP) blood glucose levels in a patient with diabetes mellitus is to prevent absorption of carbohydrate after food intake. Inhibition of these enzymes $(\alpha-$ amylase and $\alpha$-glucosidases) reduced the high postprandial (PP) blood glucose peaks in diabetes [36]. Acarbose and Miglitol are a competitive inhibitor of $\alpha$ glucosidases and reduces absorption of starch and disaccharides [35]. The $\alpha$-amylase inhibitors act as an anti-nutrient that obstructs the digestion and absorption of carbohydrates. Acarbose is complex oligosaccharides that delay the digestion of carbohydrates. It inhibits the action of pancreatic amylase in the breakdown of starch. Synthetic inhibitor causes side effect such as abdominal pain, diarrhoea and soft faeces in the colon.

The present study reveals that both encapsulated and nonencapsulated astaxanthin effectively inhibit both $\alpha$-amylase and $\alpha$ Glucosidase enzymes. Our findings were compared with other research articles. The mechanisms were investigated underlying the insulin sensitivity effects of ASX in a non-genetic insulin resistant animal model. The results showed that ASX improved insulin sensitivity by activating the post-receptor insulin signalling, i.e. enhancing the auto phosphorylation of insulin receptor-b (IR-b), IRS-1 associated PI3-kinase step, phospho-Akt/Akt ratio and GLUT-4 translocation in skeletal muscle [37].

Oxidative stress induced by hyperglycemia possibly causes the dysfunction of pancreatic $\beta$-cells and various forms of tissue damage in patients with diabetes mellitus. It was found that astaxanthin could diminish the oxidative stress caused by hyperglycemia in the pancreatic $\beta$-cells, significantly improve glucose tolerance, increase serum insulin levels, and decrease blood glucose levels [8]. Recently, 
[38] demonstrated that astaxanthin could substantially improve insulin sensitivity through abolishing significant elevation in both glucose and insulin levels induced by a high fat plus high fructose diet in mice.

But beyond that, the effects of astaxanthin in a metabolic syndrome animal model of spontaneously hypertensive corpulent rat,the results showed that astaxanthin markedly decreased the levels of blood glucose, triglycerides and non-esterified fatty acids, and significantly increased the levels of high-density lipoprotein cholesterol and adiponectin. It is suggested that astaxanthin ameliorates insulin resistance and improve insulin sensitivity by increasing glucose uptake, and by modulating the levels of circulating adiponectin and blood lipids [39].

\section{CONCLUSION}

To date, more and more metabolic diseases have influenced in human's health and quality of life. In the last few years, there has been a growing interest in the herbal medicine in care and management of diabetes both in developing and developed countries, due to their natural origin and less side effects.

The adverse effects of current drug treatment are not always satisfactory in maintaining normal levels of blood Glucose. Hence there is continuous thirst towards discovering or identification of bioactive compounds derived from plants and marine sources with potent antidiabetic activity. In the present study, the astaxanthin in free form and encapsulated form has been found to exhibit better antidiabetic potential by inhibition of Amylase and Glucosidase. Our other studies also proved their antioxidant, radical scavenging and anti-inflammatory potential. However, further research should go in this direction in order to show new preventive and potential therapeutic strategies against diabetes and associated disorders.

\section{CONFLICT OF INTERESTS}

Declare none

\section{REFERENCES}

1. Hang Wang, Zhi-ming $\mathrm{Fu}$, Chun-chao Han. The potential applications of marine bioactive against diabetes and obesity. Am J Mar Sci 2014;2:1-8.

2. IDF Diabetes Atlas. International Diabetes Federation; 2015. Available from: http://www.idf.org/idf-diabetes-atlas-seventhedition. [Last accessed on 14 Apr 2016]

3. Pontiroli AE, Camisasca R. Additive effect of overweight and type 2 diabetes in the appearance of coronary heart disease but not of stroke: a cross-sectional study. Acta Diabetol 2002;39:83-90.

4. Grundy SM, Bryan Brewer JH, Cleeman JI, Sidney J, Smith C, Lenfant C. Definition of metabolic syndrome: report of the National Heart, Lung, and Blood Institute/American Heart Association conference on scientific issues related to definition. Circulation 2004;109:433-8.

5. Higuera-Ciapara I, Félix-Valenzuela L, Goycoolea FM. Astaxanthin: a review of its chemistry and applications. Crit Rev Food Sci Nutr 2006;46:185-96.

6. Kurashige $\mathrm{M}$, Okimasu $\mathrm{E}$, Inoue $\mathrm{M}$, Utsumi $\mathrm{K}$. Inhibition of oxidative injury of biological membranes by astaxanthin. Physiol Chem Phys Med NMR 1990;22:27-38.

7. Ohgami K, Shiratori K, Kotake S, Nishida T, Mizuki N, Yazawa K, et al. Effects of astaxanthin on lipopolysaccharide-induced inflammation in vitro and in vivo. Invest Ophthalmol Visual Sci 2003;44:2694-701.

8. Uchiyama K, Naito Y, Hasegawa G, Nakamura N, Takahashi J, Yoshikawa T. Astaxanthin protects beta-cells against glucose toxicity in diabetic db/db mice. Red Rep 2002;7:290-300.

9. O'Connor I, O’Brien N. Modulation of UVA light-induced oxidative stress by beta-carotene, lutein and astaxanthin in cultured fibroblasts. J Dermatol Sci 1998;16:226-30.

10. Iwamoto T, Hosoda K, Hirano R, Kurata H, Matsumoto A, Miki $\mathrm{W}$, et al. Inhibition of low-density lipoprotein oxidation by astaxanthin. J Atheroscl Throm 2000;7:216-22.

11. Kang JO, Kim SJ, Kim H. Effect of astaxanthin on the hepatotoxicity, lipid peroxidation and antioxidative enzymes in the liver of CCl4-treated rats. Methods Find Exp Clin Pharmacol 2001;23:79-84.

12. Aoi W, Naito Y, Sakuma K, Kuchide M, Tokuda H, Maoka T, et al. Astaxanthin limits exercise-induced skeletal and cardiac muscle damage in mice. Antioxid Redox Signaling 2003; 5:139-44.

13. Leite MF, de Lima A, Massuyama M, Otton R. In vivo astaxanthin treatment partially prevents antioxidant alterations in dental pulp from alloxan-induced diabetic rats. Int Endocrinal J 2010;43:959-67.

14. Lin SF, Chen YC, Chen RN, Chen LC, Ho HO, Tsung YH, et al. Improving the stability of astaxanthin by microencapsulation in calcium alginate beads. PloS One 2016;11:1-10.

15. Park SA, Ahn JB, Choi SH, Lee JS, Lee HG. The effects of particle size on the physiochemical properties of optimized astaxanthin-rich Xanthophyllomyces dendrorhous-loaded microparticles. LWT-Food Sci Tech 2014;55:638-44.

16. Krasaekoopt W, Bhandari B, Deeth H. Survival of probiotics encapsulated in chitosan-coated alginate beads in yoghurt from UHT-and conventionally treated milk during storage. Food Sci Technol 2006;39:177-83.

17. Phathanee Thamaket, Patcharin Raviyan. Preparation and physical properties of carotenoids encapsulated in chitosan cross linked triphosphate nanoparticles. Food Appl Biosci J 2015;3:69-84.

18. Yangchao L, Boce Z, Monica W, Liangli Y, Qin W. Preparation and characterization of zein/chitosan complex for encapsulation of alpha tocopherol and Its in vitro controlled release study. Colloids Surf B 2011;85:145-52.

19. Chiu CH, Chang CC, Lin ST, Chyau CC, Peng RY. Improved hepatoprotective effect of liposome-encapsulated astaxanthin in lipopolysaccharide-induced acute hepatotoxicity. Int J Mol Sci 2016;17:1-17.

20. Bhatt UP, Sati SC, Subhash Chandra, Sudhir Kumar, Amit Anthwal, Rajendra Singh, et al. Evaluation of in vivo and in vitro antidiabetic activity of Roylea Cinerea. Int J Pharm Sci Rev Res 2015;32:210-3.

21. Malik CP, Singh MB. Plant Enzymology and Histoenzymology, Kalyani Publishers, New Delhi; 1980. p. 278.

22. Murugesan S, Anand Babu M, Bhuvaneswari S, Kotteswari M, Thennarasan S. In vitro antidiabetic activity of methanolic extracts of selected marine algae. Eur J Pharm Med Res 2015;2:256-60.

23. Narkhede MB, Ajimire PV, Wagh AE, Manoj Mohan, Shivashanmugam AT. In vitro antidiabetic activity of Caesalpina Digyna (R.) methanol root extract. Asian J Plant Sci Res 2011;1:101-6.

24. Murugesan S, Bhuvaneswari S, Sivamurugan V. Evaluation of in vitro antidiabetic activity of red seaweed Portieria Hornemannii (Lyngbye) (Silva) and Spyridia Fusiformis (Wulfen). World J Pharma Sci 2016;4:415-9.

25. Xiao Z, Storms R, Tsang A. A quantitative starch-iodine method for measuring alpha-amylase and glucoamylase activities. Anal Biochem 2006;351:146-8.

26. Ashok Kumar BS, Saleemulla Khan, Gopi Setty Saran, Nandeesh, Manjunath NK. In vitro antidiabetic activity of nisamalaki churna. Sains Malaysiana 2013;42:625-8.

27. Krishnaveni S, Theymoli B, Sadasivam S. Phenol sulfuric acid method. Food Chem 1984;15:229.

28. Andrade-Cetto A, Becerra-Jimenez J, Cardenas-Vazquez R. Alfaglucosidase-inhibiting activity of some mexican plant used in the treatment of type-2 diabetes. J Ethnopharm 2008;116:27-32.

29. Matsuura H, Asakawa C, Kurimoto M, Mizutani J. Alphaglucosidase inhibitor from the seeds of balsam pear (Momordica charantia) and the fruit bodies of Grifola frondosa. Biosci Biotech Biochem 2002;66:1576-8.

30. Tietz NW. In: Burtis CA, Ashwood ER. Eds. Tietz Textbook of Clinical Chemistry. Third Ed. Saunders WB; 1999. p. 750-78.

31. Kim YM, Wang MH, Rhee HI. A novel alpha-glucosidase inhibitor from pine bark. Carbohydr Res 2004;339:715-7.

32. Tonmoy Ghosh, Khushbu Bhayani, Chetan Paliwal, Rahulkumar Maurya, Kaumeel Chokshi, Imran Pancha, et al. Cynobacterial pigments as natural anti-hyperglycemic agents: an in vitro study. Front Marine Sci 2010;3:1-10. 
33. Frier BM, Fisher M. Diabetes mellitus. In: Boon NA, Colledge NR, Walker BR, Hunter JAA. Ed. Davidson's principle and practice of medicine. 20th ed. (Churchill Livingstone Elsevier: Ediburgh; 2006. p. 805-45.

34. Puls W, Keup U, Krause HP, Thomas G, Hoffmeister F. Glucosidase inhibition. A new approach to the treatment of diabetes, obesity, and hyperlipoproteinaemia. Naturwiss 1997;64:536.

35. Davis SN, Granner DK. Insulin, oral hypoglycemic agents and the pharmacology of endocrine pancreas. In: Brunton LL, Lazo JS, Parker KL. Ed. Goodman and Gilman's: The pharmacological basis of therapeutics. 11th ed. (McGraw-Hill Medical Publication Division: New York; 2001. p. 1706-7.

36. Conforti F, Statti G, Loizzo MR, Sacchetti G, Poli F, Menichini F. In vitro antioxidant effect and inhibition of alpha-amylase of two varieties of Amaranthus caudatus seeds. Biol Pharm Bull 2005;28:1098-1102.

37. Elumalai Arunkumar, Saravanan Bhuvaneswari, Carani Venkatraman Anuradha. An intervention study in obese mice with astaxanthin, a marine carotenoid-effects on insulin signaling and pro-inflammatory cytokines. Food Func 2012;3:120-6.

38. Bhuvaneswari S, Arunkumar E, Viswanathan P, Anuradha CV. Astaxanthin restricts weight gain, promotes insulin sensitivity and curtails fatty liver disease in mice fed an obesitypromoting diet. Process Biochem 2010;45:1406-14.

39. Hussein G, Nakagawa T, Goto H, Shimada Y, Matsumoto K, Sankawa U, et al. Astaxanthin ameliorates features of metabolic syndrome in SHR/NDmcr-cp. Life Sci 2007;80:522-9.

40. Suganya V, Asheeba ST. Microencapsulation of astaxanthin using ionotropic gelation method isolated from three crab varieties. Int J Cur Pharm Res 2015;7:96-9.

\section{How to cite this article}

- V Suganya, V Anuradha, M Syed Ali, P Sangeetha, P Bhuvana. In vitro antidiabetic activity of microencapsulated and nonencapsulated astaxanthin. Int J Curr Pharm Res 2017;9(5):90-96. 